\title{
PENDAYAGUNAAN CITRAAN DALAM TEKS SYAIR SURAT KAPAL MASYARAKAT MELAYU INDRAGIRI VERSI ANANG KASIM
}

(Utilization of Imagery in Anang Kasim's Version of Anang Kasim's Version of the Syair Letters of the Ship from the Indragiri Malay Community)

\author{
Oleh : Sri Rahayu \\ E-mail : $\underline{\text { Srirahayu@edu.uir.ac.id }}$
}

*) Program Studi Pendidikan Bahasa dan Sastra Indonesia FKIP UIR

\begin{abstract}
ABSTRAK
Pola penerapan citraan yang digunakan oleh penyair dalam sebuah karya sastra khususnya Teks Syair Surat Kapal dapat mempengaruhi kualitas Teks Syair Surat Kapal tersebut. Pesan-pesan yang ingin disampaikan melalui karya sastra harus kreatif supaya terkesan menarik untuk dibaca maupun didengar, maka diperlukannya ciri dan pola yang khusus terutama dalam bidang citraan itu sendiri untuk membuat karyanya menjadi indah dan menarik. Banyak cara untuk menikmati, memahami dan menghayati hasil karya dari pengarang salah satunya adalah dengan pengkajian Pendayagunaan Citraan dalam Teks Syair Surat Kapal Masyarakat Melayu Indragiri Versi Anang Kasim. Oleh karena itu, tujuan penelitian ini menganalisis dan mengiterpretasikan Pendayagunaan Citraan dalam Teks Syair Surat Kapal Masyarakat Melayu Indragiri Versi Anang Kasim. Hal tersebut perlu untuk diteliti karena eksitensi sebuah karya sastra dapat dilihat dari bagaimana cara pengarang mengemas hasil karyanya sehingga dapat menciptakan pola dan gaya tersendiri dari sisi pengarang. Penelitian ini bersifat deskriptif dengan metode content analysis. Data penelitian ini bersumber dari buku Syair Surat Kapal Masyarakat Melayu Indragiri Karya Dedi Iswanto Tahun 2007. Data yang diteliti didokumentasi dengan cara membaca, mencatat selanjutnya disimpulkan dan dikelompokkan berdasarkan pola penerapan citraan dalam Teks Syair Surat Kapal Masyarakat Melayu Indragiri Versi Anang Kasim. Berdasarkan pengamatan penulis, Teks Syair Surat Kapal Masyarakat Melayu Indragiri Versi Anang Kasim tersebut memiliki pola penerapan pendayagunaan citraan yang unik dan khas dilihat dari aspek stilistika yaitu citraan yang berkualitas sehingga pembaca mampu menikmati dan memaknai makna tersurat maupun tersirat dari syair tersebut.
\end{abstract}

Kata Kunci : Pendayagunaan, Citraan, Syair Surat Kapal

\section{ABSTRACT}

The pattern of image application used by poets in a literary work, especially the text of the ship's verse, can affect the quality of the text of the ship's verse. The messages to be conveyed through literary works must be creative so that they appear attractive to read and listen to, so special characteristics and patterns are needed, especially in the field of image itself, to make his work beautiful and attractive. There are many ways to enjoy, understand and appreciate the work of the author, one of which is to study the Utilization of Imagery in Anang Kasim's Version of the Syair Surat Kapal of the Indragiri Malay Community. Therefore, the aim of this study is to analyze and interpret the Utilization of Images in Anang Kasim's Version of the Syair Surat Kapal of the Indragiri Malay Community. This needs to be examined because the existence of a literary work can be seen from how the author packages his work so that he can create its own patterns and styles from the author's side. This research is descriptive with content analysis method. The data of this research are sourced from the book Syair Surat Kapal Masyarakat Melayu Indragiri Karya Dedi Iswanto 2007. The data studied were documented by reading, taking notes, then summarized and grouped based on the pattern of applying images in Anang Kasim's version of Anang Kasim's version of Syair Surat Kapal Surat 
Melayu Indragiri Community. Based on the author's observations, the text of Anang Kasim's version of the Syair Surat Kapal Melayu Indragiri version has a unique and distinctive pattern of application of imagery utilization seen from the stylistic aspect, namely quality imagery so that readers are able to enjoy and interpret the express and implied meanings of the verse.

Keyword: Utilization, Imagery, Syair Letters of the Ship

\section{PENDAHULUAN}

Pola penerapan citraan dalam sebuah karya sastra sangat penting diterapkan oleh penyair dalam menciptakan sebuah karya sastra dalam hal ini agar syair tersebut memiliki kualitas yang baik bagi penikmatnya. Penelitian ini dilatarbelakangi oleh pentingnya penerapaan citraan dalam sebuah karya sastra dalam hal ini syair

Sebuah karya sastra memiliki ungkapan-ungkapan bahasa tertentu yang seringkali melibatkan fungsi panca indera di dalam teks-teks sastra. Seolah-olah pembaca yang membacanya bisa melihat dan mendengar secara imajinatif. Penggambaran yang awal mulanya tampak abstrak melalui ketepatan penggunaan indera dalam teks menjadikan gambaran teks lebih konkret dan jelas. Sebagaimana dipertegas Nurgiantoro (2014: 275) “ Penggunaan kata-kata dan ungkapan yang mampu membangkitkan tanggapan indra yang demikian dalam karya sastra tersebut sebagai citraan". Selanjutnya pendapat yang tidak jauh berbeda, yaitu pendapat ahli yang mengemukakan bahwa citraan merupakan suatu bentuk penggunaan bahasa yang mampu membangkitkan kesan yang konkret terhadap suatu objek, pemandangan, aksi, tindakan, atau pernyataan yang dapat membedakannya dengan pernyataan atau ekspositori yang abstrak dan biasanya ada kaitannya dengan simbolisme (Baldic, 2001 : 121-122 dalam Nurgiyantoro, : 276). Sedangkan Menurut

Efendi (1974:46) dalam Nurgiantoro ( 2014:277) menegaskan bahwa citraan atau istilah pengimajian merupakan jiwa puisi, jiwa persajakan. "Pengimajian adalah penataan kata yang menyebabkan maknamakna abstrak menjadi konkret dan cermat". Kekonkretan dan kecermatan makna-makna itu mengunggah kekonkretan dan kecermatan penglihatan atau pendengaran imajian pembaca.

Dengan demikian, dari penjelasan tersebut pembicaraan pengertian citraan sangatlah luas. Pada pembahasan selanjutnya peneliti fokus pada spesifik macam citraan yang akan digunakan dalam menganalisis macam citraan dalam sebuah teks karya sastra yaitu syair surat kapal Masyarakat Melayu Indragiri Versi Anang Kasim. Alasan peneliti menjadikan kajian penelitian adalah sebab menjadikan sastera yang dimiliki bumi melayu mendapat tempat dalam ranah sastera yang lebih luas. Kearifan lokal dan budaya yang terkandung di dalam syair Anang Kasim menjadi daya tarik serta citraan di dalamnya perlu dikaji seberapa kuat pendayagunaan citraan dalam sebuah karya.

Sebagai contoh citraan yang terdapat syair surat kapal versi Anang Kasim yaitu :

Hanya Allah Tuhan yang satu

Tiada beranak tiada beribu

Tidaklah pula punyai sekutu

Wajiblah kita sujud bersimpu 
Kutipan data 1 larik 4 pada syair tersebut menunjukkan bahwa pengarang menggunakan citraan gerak (kinestetik). Dimana pengarang lewat syair yang ditulis, seolah mengingatkan kepada pembaca bahwa sujud bersimpu tersebut adalah cara manusia untuk wajib melaksanakan perintah Allah Swt seperti salat lima waktu. Sebagai bukti percaya akan keimanan kepada Allah. Sujud brsimpu adalah citraan gerak karena merupakan suatu aktivitas atau gerak motorik.

\section{METODE PENELITIAN}

Penelitian ini menggunakan desain penelitian kualitatif deskriptif dengan instrumen penelitian berupa buku Syair Surat Kapal Masyarakat Melayu Indragiri Dedi Iswanto terbitan Maret 2007 khususnya Syair Surat Kapal Versi Anang Kasim. Kegiatan penelitian ini dibuat pada bulan Januari- Maret 2021 dimulai dari kegiatan, perencanaan, penelitian dengan pengajuan proposal sampai pada tahap laporan hasil penelitian . Metode yang digunakan dalam mengumpulkan data yaitu metode deskriptif dan analisis isi yaitu dengan mengumpulkan dan mengklasifikasi kutipan yang mengandung unsur citraan dalam syair tersebut. Kemudian kutipan tersebut yang terdapat unsur-unsur citraan akan dijadikan sampel peneitian. Berikutnya sampel penelitian tersebut dianalisis sesuai dengan teori tentang citraan.

Berdasarkan pengumpulan data yang dilakukan oleh peneliti tentang Pendayagunaan Citraan dalam Teks Syair Surat Kapal Masyarakat Melayu Indragiri Versi Anang Kasim khususnya syair dikaji dari aspek macam citraan yaitu : Citraan pendengaran (visual), citraan pendengaraan (auditif), citraan gerak (kinestetik), citraan rabaan (taktil termal) dan citraan peciuman (olfaktori).

\section{HASIL}

Tabel 1. Pendayagunaan Citraan dalam Teks Syair Surat Kapal Masyarakat Melayu Indragiri Versi Anang Kasim. (Bagian Perhelatan Wafdi dan Neli)

\begin{tabular}{|c|l|l|l|l|l|l|}
\hline \multirow{2}{*}{ No } & \multicolumn{1}{|c|}{ Syair } & $\begin{array}{l}\text { Penglihatan } \\
\text { (Visual) }\end{array}$ & $\begin{array}{l}\text { Pendengaran } \\
\text { (Auditoris) }\end{array}$ & $\begin{array}{l}\text { Gerak } \\
\text { (Kinestetik) }\end{array}$ & $\begin{array}{l}\text { Rabaan } \\
\text { (Taktil Termal) }\end{array}$ & $\begin{array}{l}\text { Penciuman } \\
\text { (Olfaktori) }\end{array}$ \\
\hline 1. & $\begin{array}{l}\text { Hanya Allah Tuhan } \\
\text { yang satu } \\
\text { Tiada beranak tiada } \\
\text { beribu } \\
\text { Tidaklah pula } \\
\text { punyai sekutu } \\
\text { Wajiblah kita sujud } \\
\text { bersimpu }\end{array}$ & & \multicolumn{1}{|c|}{} & \\
\hline 2. & $\begin{array}{l}\text { Bukanlah adat } \\
\text { tetapi kebiasaan } \\
\text { Sastera Melayu } \\
\text { kami } \\
\text { senandungkan } \\
\text { Peninggalan } \\
\text { Melayu }\end{array}$ & $\sqrt{c}$ & & \\
\hline
\end{tabular}




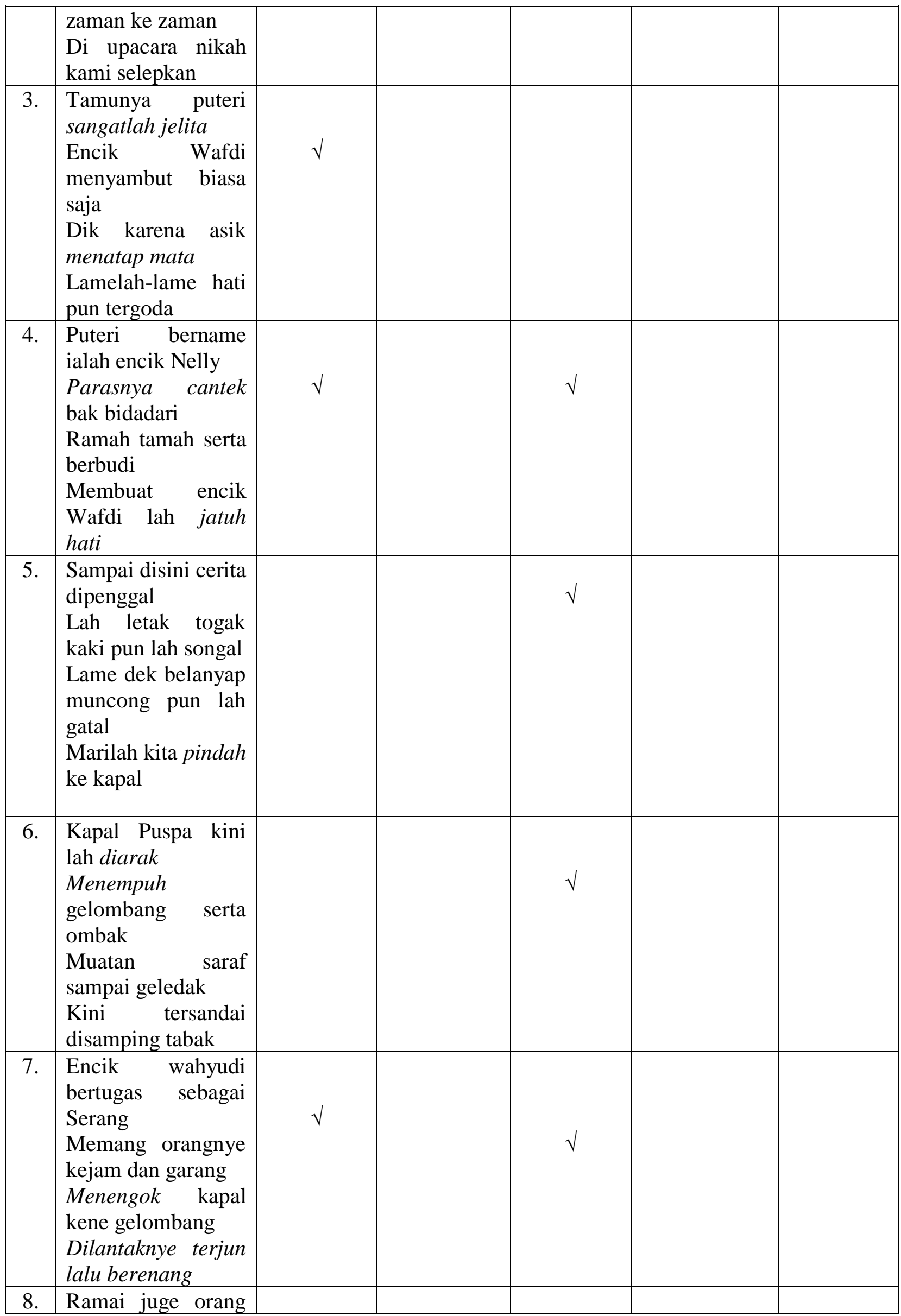




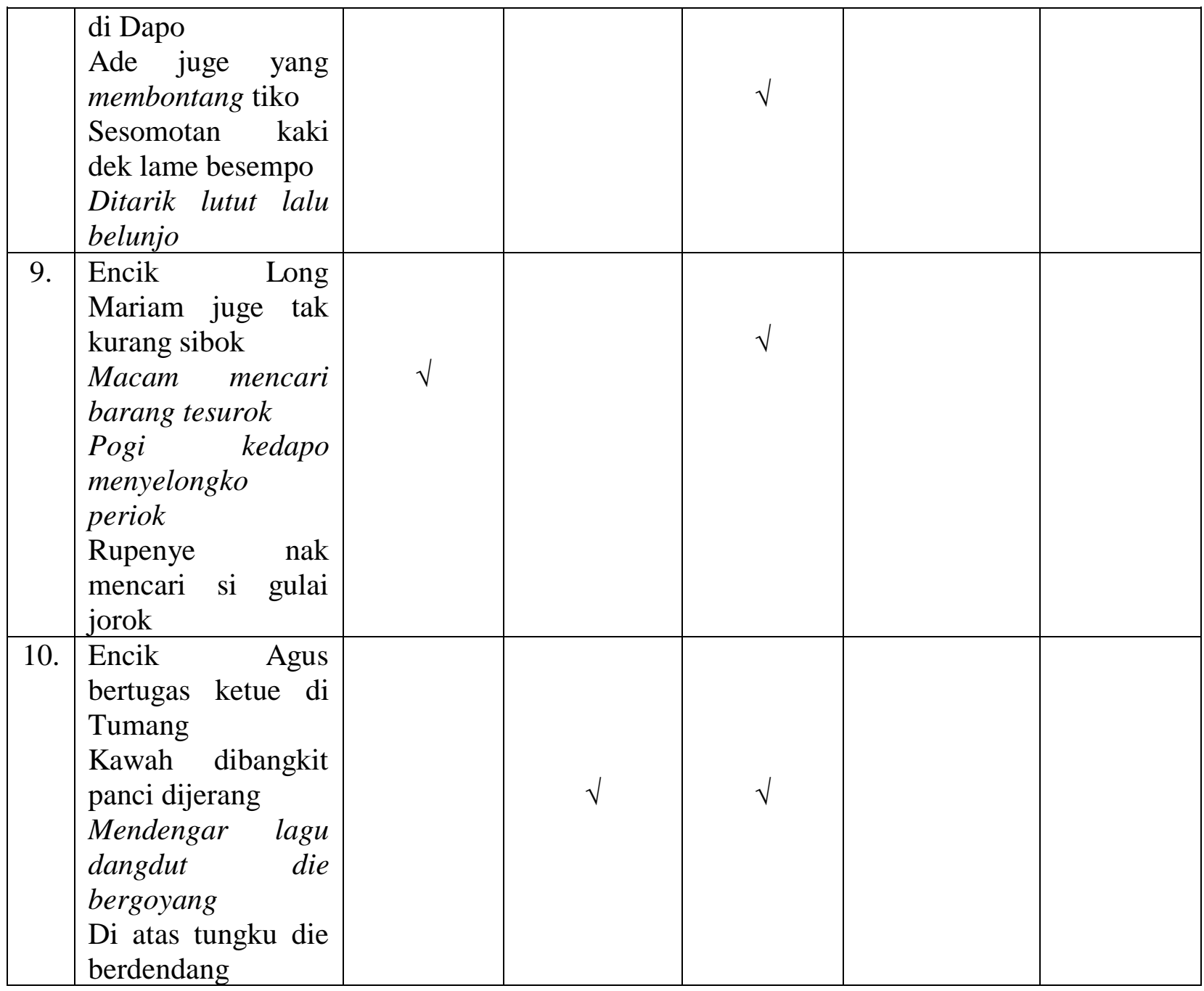

\section{PEMBAHASAN}

Data 1

Hanya Allah Tuhan yang satu

Tiada beranak tiada beribu

Tidaklah pula punyai sekutu

Wajiblah kita sujud bersimpu

Kutipan data 1 larik 4 pada syair tersebut menunjukkan bahwa pengarang menggunakan citraan gerak(kinestetik).

Dimana pengarang lewat syair yang ditulis, seolah mengingatkan kepada pembaca bahwa sujud bersimpu tersebut adalah cara manusia untuk wajib melaksanakan perintah Allah Swt seperti salat lima waktu. Sebagai bukti percaya akan keimanan kepada Allah. Sujud brsimpu adalah citraan gerak karena merupakan suatu aktivitas atau gerak motorik.

Data 2

Bukanlah adat tetapi kebiasaan

Sastera Melayu kami senandungkan

Peninggalan Melayu Riau zaman ke zaman Di upacara nikah kami selepkan

Kutipan data 2 larik 2 pada syair tersebut menunjukkan bahwa pengarang menggunakan citraan pendengaran (auditif). Dimana pengarang ingin menunjukkan bahwa masyarakat melayu Riau menjunjung tinggi adat kebiasaan (budaya) melalui menyandungkan sastera melayu. Melalui citraan tersebut pembaca seolah dapat mendengar bunyi dari sastera melayu oleh para tetua. 
Data 3

Tamunya puteri sangatlah jelita

Encik Wafdi menyambut biasa saja

Dik karena asik menatap mata

Lamelah-lame hati pun tergoda

Data 4

Puteri bername ialah encik Nelly

Parasnya cantek bak bidadari

Ramah tamah serta berbudi

Membuat encik Wafdi lah jatuh hati

Kutipan data 3 dan 4 mempunyai citraan yang sama yaitu citraan penglihatan (visual ). Dimana pengarang membuat kita seolah-olah dapat melihat objek yang digambarkan pengarang secara konkret walau hanya di dalam rongga imajinasi dan pengarang menjembatani kemudahan dalam memahami, khususnya tokoh Encik Neli dalam syair tersebut. Dan di dalam data 4 larik ke 4 mengandung secara tersirat citraan gerak yaitu jatuh hati, karena gerak tidak hanya diartikan perpindahan tetapi juga bisa dorongan (batin/perasaan)

Data 5

Sampai disini cerita dipenggal

Lah letak togak kaki pun lah songal

Lame dek belanyap muncong pun lah gatal Marilah kita pindah ke kapal

Kutipan data 5 pada larik ke 5 adalah citraan gerak (kinestetik) karena adanya suatu perpindahan atau aktivitas. Dalam teks syair tersebut pengarang menunjukkan bahwa cerita diringkas lalu dilanjutkan Kutipan data 8 pada larik 2 dan 4 adalah larik syair yang mengandung citraan gerak (kinestetik), dimana pengarang menyampaikan dan kita pembaca seolah dapat merasakan aktivtias membentang IMPLIKASI

Berdasarkan hasil pembahasan dan analisis tentang Pendayagunaan Citraan dalam Teks Syair Surat Kapal Masyarakat Melayu Indragiri Versi Anang Kasim pada bagian lain yaitu pindah, dalam syair pindah ke kapal. Seolah pembaca mengikuti alur yang disampaikan pengarang.

Data 6

Kapal Puspa kini lah diarak

Menempuh gelombang serta ombak

Muatan saraf sampai geledak

Kini tersandai disamping tabak

Kutipan data 6 pada larik 1 dan 2 mengandung citraan gerak (kinestetik), dimana terdapat kata diarak dan menempuh yang merupakan suatu aktivitas, seolah-olah pembaca dapat melihat kapal tersebut yang sedang melewati gelombang dan ombak. Sampai akhirnya sampai di pelabuhan.

Data 7

Encik wahyudi bertugas sebagai Serang Memang orangnye kejam dan garang

Menengok kapal kene gelombang

Dilantaknye terjun lalu berenang

Kutipan data 7 pada larik 3 dan 4 mengandung citraan penglihatan dan gerak. Citraan penglihatan terjadi karena ada kata yang mengandung unsur seolaholah pembaca dapat melihat dan merasakan.

Data 8

Ramai juge orang di Dapo

Ade juge yang membontang tiko

Sesomotan kaki dek lame besempo

Ditarik lutut lalu belunjo

tikar di dapur dan ketika kaki kesemutan pengarang memberikan aktivitas atau gerakan yaitu menarik lutut lalu menyandar (berisitrahat).

dalam Syair dari aspek stilistika citraan disimpulkan bahwa pengarang memiliki pola penerapan citraan yang cukup beragam/berkualitas dalam mendukung 
peningkatan kualitas syair yang diciptakannya. Pengarang menggunakan citraan dalam syair berbagai macam citraan dalam menciptakan syair diantaranya citraan penglihatan, citraan pendengaran dan citraan gerak yang terlihat lebih dominan dii dalam syair

\section{REFERENSI}

Abidin, Zainal. 2010. „, “Analisis Stilistika Pantun Manjopuik Limau Desa Benai Kabupaten Kuantan Sengingi”. Skripsi. Pekanbaru: FKIP Universitas Islam Riau.

Arpen, Hidayat. 2016. "Analisis Gaya Bahasa dan Makna Pantun Adat Perkawinan Desa Tanjung Kecamatan Koto Kampar Hulu Kabupaten Kampar". Skrips. Pekanbaru: FKIP Universitas Islam Riau Pekanbaru.

Rahayu, Sri dan Alber 2020. “ Stile Kepengarangan Tenas Efendy Dala Tunjuk Ajar Melayu”. Jurnal Geram. Pekanbaru : PBSI FKIP Universitas Islam Riau.

Endraraswara, Suwanda, 2011. Metodologi Penelitian Sastra (Epistemologi, Model, Teori, dan Aplikasi). Yogyakarta: CAPS.

Ernawati, Waridah, 2013. Ejaan yang Disempurnakan dan Seputar Kebahasaan Indonesia. Bandung: Ruang Kata.

Fatimah, Rezki Puteri Syahrani Nurul. 2015. „"Tunjuk Ajar Melayu dalam Pantun Adat Perkawinan Melayu Kelurahan Daik Kabupaten Lingga Kepulauan Riau eee. Jurnal Bahas Volume 10 Nomor 2 Oktober. (http://www.google.co.id, diakses 25 Juli 201709:25.

Hamidy, UU. 2005. Pembahasan Karya Fiksi dan Puisi. Pekanbaru: Unri Press. tersebut. Dengan adanya citraan yang berkualitas maka syair tersebut memiliki kadar kualitas yang tinggi di mata pembaca atau penikmat syair tersebut.

\section{Jagad Melayu dalam Lintasan Budaya. Pekabaru: Bilik Kreatif Pres.}

Keraf, Gorys. 2010. Diksi dan Gaya bahasa. Jakarta: Gramedia Pustaka Utama.

Kridalaksana, H.2008. Kamus linguistik. Jakarta: PT. Gramedia Pustaka Utama.

Krippendorff, Kalus. 1991. Analisis Isi: Pengantar Teori dan Metodologi. Jakarta: Rajawali Pers.

Mahsun. 2007. Metode Penelitian Bahasa. Jakarta: PT Raja Grafindo Persada

Nurgiyantoro, Burhan. 2014. Stilistika. Yogyakarta: Gadjah Mada University Press.

Pusat Pembinaan dan Pengembangan Bahasa. 2008. Kamus Besar Bahasa Indonesia: Edisi ke-4. Jakarta: Gramedia Pustaka Utama

Ratna, Nyoman Kutha.2009. Stilistika: Kajian Puitika Bahasa Sastra dan Budaya. Yogyakarta: Pustaka Pelajar.

Rokhmansyah. 2014. Studi dan Pengkajian Sastra: Perkenalan Awal Terhadap Ilmu Sastra. Yogyakarta: Graha Ilmu.

Sikana, Mana. 1990. Pendekatan Kesusastraan Modern. Bani Selangor: Penerbit Karyawan.

Sudjiman, Panuti. 1993. Bunga Rampai Stilistika. Jakarta:Grafiti.

Sugiyono. 2014. Memahami Penlitian Kulitatif. Bandung: Alfabeta. 